\title{
Plymouth, Montserrat: Apocalyptic Dark Tourism at the Pompeii of the Caribbean
}

\begin{tabular}{|r|l|}
\hline Journal: & International Journal of Tourism Cities \\
\hline Manuscript ID & IJTC-08-2017-0040.R1 \\
\hline Manuscript Type: & Case Study in City Tourism \\
\hline Keywords: & Apocalypse, Tourism, Montserrat, Caribbean, Disaster, Dark Tourism \\
\hline \multicolumn{2}{|c}{} \\
\hline
\end{tabular}

\section{SCHOLARONE"}

Manuscripts 


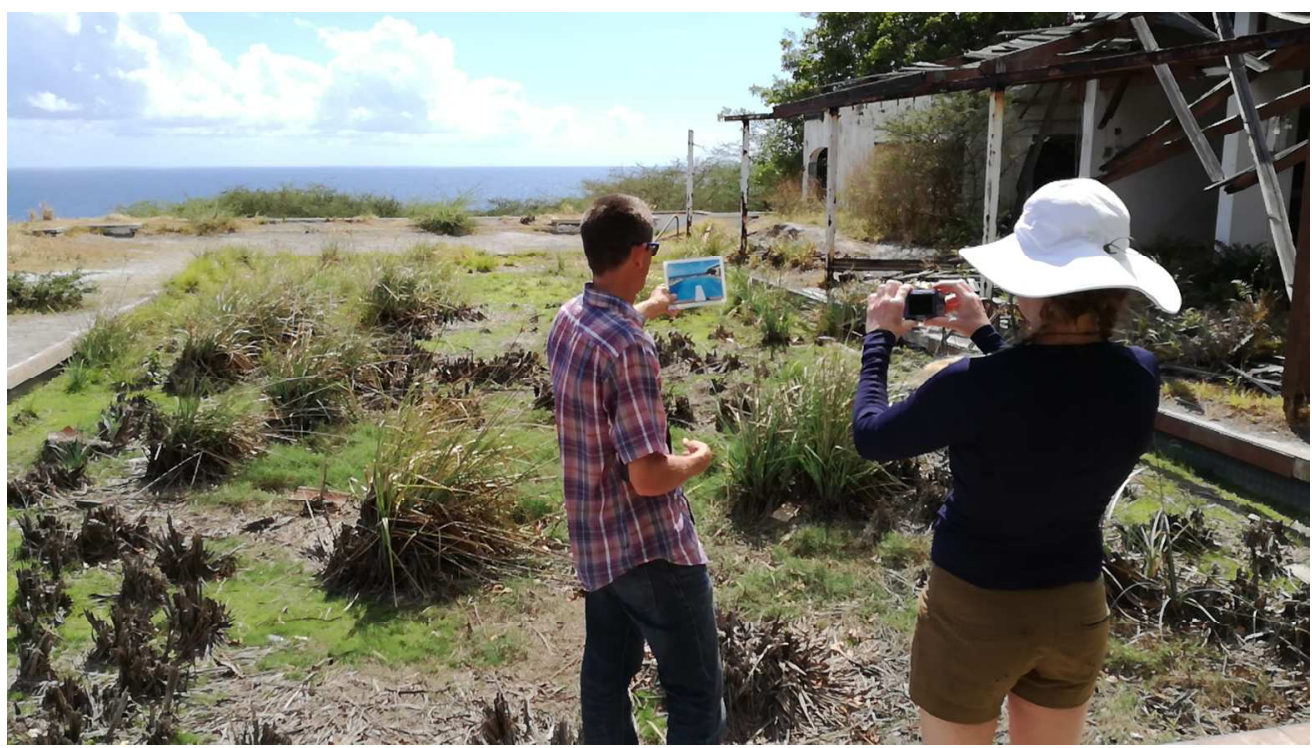

Tour guide showing tourist the Montserrat Springs Hotel swimming pool before and after the volcano disaster

$677 \times 381 \mathrm{~mm}(72 \times 72 \mathrm{DPI})$ 


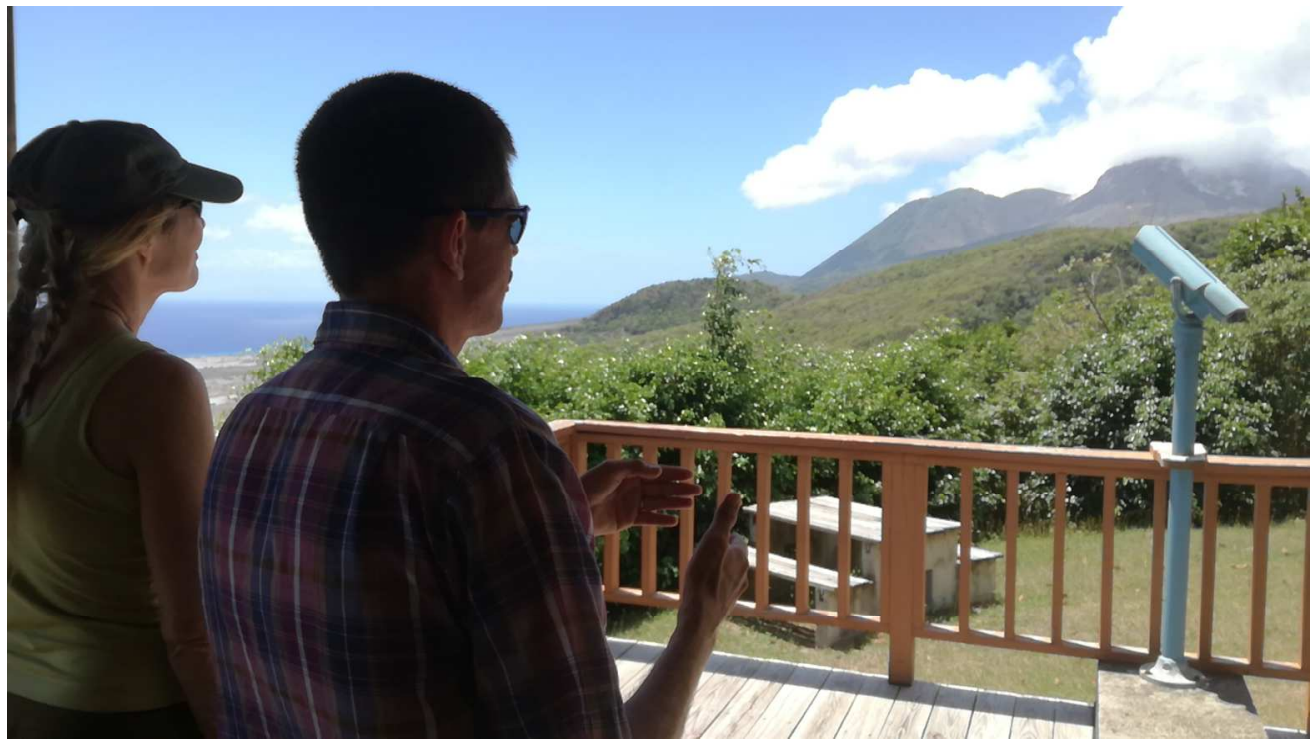

Tour guide explaining pyroclastic flows across eastern Montserrat to tourist, Jack Boy Hill viewing facility $677 \times 381 \mathrm{~mm}(72 \times 72 \mathrm{DPI})$ 


\title{
Plymouth, Montserrat: Apocalyptic Dark Tourism at the Pompeii of the Caribbean
}

\begin{abstract}
I Purpose - The purpose of this paper is to present contrasting approaches to the descriptive case study of tourism to the buried city of Plymouth, Montserrat, an example of the marketing and burying - the supply and demand - of apocalyptic dark tourism on the island

| Design/methodology/approach - A case study mixed methods methodology is adopted and findings are derived from tour guiding fieldwork, guide and tourist interviews, and an analysis of travel writing and tourism marketing campaigns.

Findings - Dark tourism is viewed as a contentious and problematic concept: it attracts and repels tourism to the former capital Plymouth, Montserrat. Twenty years into the volcano crisis, the islanders, government and Tourist Board are commemorating resilience living with the volcano and regeneration in a disaster scenario. Marketing and consumption approaches to dark tourism elucidate different facets to the case study of 'the buried city' of Plymouth, Montserrat, and the Montserrat Springs Hotel overlooking Plymouth. The disjunct between these two types of approach to dark tourism, as well as the different criteria attached to working definitions of dark tourism - and the range of interests in apocalyptic dark tourism into the city and its surrounds, show some of the problems and limitations with theoretical and scalar discussions on dark tourism.
\end{abstract}

Research limitations/implications - The paper's implications are that both supply and demand approaches to dark tourism are needed to fully understand a dark tourism destination and to reconcile the disjunct between these two approaches and the perspectives of tourist industry and tourism users.

| Originality/value - This is a descriptive dark tourism case study of a former capital city examined from both supply and demand perspectives. It introduces the apocalyptic to dark tourism destination analysis.

Keywords Apocalypse, Tourism, Montserrat, Caribbean, Disaster, Destination marketing, Dark Tourism

Paper type Case study

Today, Plymouth and its environs stand abandoned and frozen in time, looking like the set of an apocalyptic sci-fi movie. Behind the locked gates prohibiting entry into the "Exclusion Zone," a deep drift of mud, lava and ash almost buries the clock tower of the former courthouse and rises to the upper stories of other buildings, prompting descriptions of a modern-day Pompeii. (Bachelor, 2014)

\section{Introduction}

The city is an emblem of modernity. It is a landscape of opportunity and main point of departure and destination for tourism. Globally, the city trip has seen soaring growth between 2007 and 2016 to represent $22 \%$ of all global holidays. In Europe, by 2014, city trips had grown to represent some $20 \%$ of all holiday trips. The ITB World Travel Trends Report 2015/2016 (ITB, 2016, p. 25) reports that, [i]n 2014, Europeans made nearly 70 million city trips to international destinations, a $60 \%$ rise on 2007 which corresponds to $7 \%$ per year, and booked about 400 million overnight stays'. In the UK, ABTA records a rise in the popularity of the city break as opposed to the beach holiday, from parity of $41 \%$ of all tourism in 2013 (ABTA, 2013), to $53 \%$ city breaks versus $38 \%$ beach holiday by 2016 (ABTA, 2016, p. 4). Typically, the majority of tourists on city breaks have similar motivations to each other: 'sightseeing, enjoying the city atmosphere, shopping, eating out, and visiting cultural attractions' (ITB, 2016, p. 24). And yet there are some tourists motivated to seek out places of death and disaster, referred to as 'dark tourists' if it is considered to be a contemporary Late to Post Modern phenomenon (Lennon and Foley, 2004), or 'thanatourists' if it is held to be a more embedded human practice stemming from the Christian obsession with death (Seaton 1996, 2009). A controversial term (unhelpful, sensational, and not politically correct [Bowman and Pezzullo 2009]), one critiqued (from supply or demand [Biran and Poria, 2012], or psychological perspective [Buda, 2015]) and typologised (placed on a slippery 
continuum [Stone, 2006; Hepburn, 2012]), 'dark tourism' has the potential to drive niche tourism in some of the world's most visited cities - 'dark cities' according to Powell and Kennell (2016).

The dark tourism concept used in this paper is applied to a non-orthodox dark tourismsetting in terms not just of developing world setting associated with geological phenomenon but also in juxtaposing the 'apocalyptic' with dark tourism. This is a deliberate juxtapositioning that is in keeping with the recent opening out of conceptualisations of dark tourism. In tourism research, dark tourism is now being applied to an increasing number of locations and experiences. Frew and White (2013) take a visitor motivation and destination management dual approach in their recent volume Dark Tourism and P lace İdentity. They, in particular, acknowledge the open-ended nature of dark tourism with its connection to the following related terms:

battlefield tourism, heritage tourism, cultural tourism, thanatourism, atrocity tourism, morbid tourism, grief tourism, doomsday tourism, dissonant heritage, conflict heritage, undesirable heritage, negative heritage, dark events, dark exhibitions, dark shrines, dark conflict sites, dark camps of genocide, place perception, place branding and destination marketing. (White and Frew, 2013: 277)

In short, the post-Millennium shift is away from Auschwitz and Alcatraz (cf. Miles, 2002; Strange and Kempa, 2003) conventional dark tourism destinations - from dark tourism at the museum and dark tourism at the memorial - to more diverse locations including exploring sites of natural disaster such as in Phuket, Thailand (Rittichainuwat, 2008); or walking slum tours of Mumbai, Nairobi or Rio de Janeiro (cf. Zeiderman, 2006; Frenzel, 2013). Performance scholar Emma Willis (2014) takes this movement into the performing of dark tourism by adding the theatrical performances at dark tourism sites such as Butare, Rwanda, where 6000 Tutsis were slaughtered. Her progressive point is to draw attention to issues of contemporary witnessing and ethical spectatorship. Conceptually, Miller and Gonzalez (2013) add death tourism to Mexico for high animal dose tranquilizers or to Dignitas in Zurich for assisted suicide to the growing dark tourism sub-categories. These examples retain the received understanding of dark tourism's association with death, disaster and atrocity, thus excluding Cohen and Gössling's (2015) recent research into the social isolation and spatial disorientations of flying long haul - what they refer to as "the darker side of hypermobility'. They also force a brutal but not brutalizing connection between the tourist and the tourist destination that changes the tourist, often profoundly: for environmentalist Phaedra Pezzullo, the dark tourism sites 'interpellate the tourist'; for anthropologist Erica Robb $(2009,58)$, 'dark tourism occupies a tense intermediary zone between voyeurism and social justice'. Dark tourism has indeed become the new contact zone. This paper engages with that contact zone in the Caribbean, where tourists play out their post-apocalyptic, postfin-de-siècle concerns.

Where Powell and Kennell (2016) examined, by content analysis, EU cities and their 'dark products', this paper presents and examines the case for or against dark tourism to Plymouth, Montserrat in the Eastern Caribbean, billed as 'the Pompeii of the Caribbean' (Reffes, 2016), 'a modern-day Pompeii in the Caribbean' (Bachelor, 2014), an 'intriguing Pompeii in the Tropics' (Caribbean Travel WebsiteAnon., 2016), 'the "Caribbean Pompeii'”'(Schuessler, 2016), 'a Pompeii-style ash heap' (AnonMontserrat Reporter=, 2003) with respect to supply and demand perspectives. The paper also assesses whether or not tourism to Plymouth, a town buried by pyroclastic mudflow - a former town, a new nonspace appealing to an urban imaginary often referred to as a city - is indeed a case of niche city tourism. The first section considers the history of Plymouth, 'capital' of Montserrat, now lost and buried, with its citizens and services all relocated to the suburbs and to only recently purpose-built accommodation in the north of the island. The following section applies the
Formatted: js indent

Formatted: Font: (Default) Times New Roman, 12 pt

Formatted: Font: Italic

Formatted: Font: (Default) Times New Roman

Formatted: Font: $12 \mathrm{pt}$

Formatted: Normal, Don't adjust space between Latin and Asian text, Don't adjust space between Asian text and numbers

Formatted: $j \mathrm{~s}$ indent 
supply and demand approaches to dark tourism to this case study ranging from the marketing and the promotion of the island - this part of it in particular - and to the tour guiding experience developed for the discerning visitor to this 'desolate' destination. It suggests that there is a disjunct between these two types of approach, and the diversity of tours into the buried city, and highlights some of the problems and limitations with theoretical and scalar discussions on dark tourism.

\section{A note on methods}

This descriptive paper case study derives from a mixed methods_-research approach to research and interpret data for the case study. This 'methodological pluralism' (cf. Heesen, Bright and Zucker, 2016) serves to develop a coherent and comprehensive framework for triangulation (see Table 1.0). Triangulation has been shown to improve the degree of confidence in the data gathered and the validity of its analysis (Jack and Raturi, 2006). In this case study it also provides additional dimensions to the same phenomenon under investigation from different island (from citizen to Tourist Board and tourist industry operators) and consumer perspectives: this blended research triangulates through-involving long_-term participant observation with, regular follow-up visits to the island; semistructured interviews with key individuals over the duration of the crisis $;$; online tracking and archiving of digital marketing strategies and a netnography of the online presence, profile and news relating to the island on social media and in the British and local Montserratian press. This is a comprehensive approach triangulating upon attitudes, approaches and reactions to the on-going volcanic eruption on Montserrat that led to an evacuation of the capital, its burial in pyroclastic material, and its recent exhumation as a working port and tourist destination. The data is accumulative and derived from the range of research methods used was subsequently searched for keywords, and analysed for themes and specific content. Specifically, long term participant observation was undertaken 1994 to 1995 for ten months on the island examining issues surrounding identity and tourism with reference to 'Black Irish' relations and the celebration or commemoration of St Patrick's Day - the day of a failed slave insurrection in 1768 (Xxxxx Skinner, 2004; SkinnerXxxxxy, 2015a). The on-going volcano crisis started at the tail--end of this fieldwork ethnography where the notions and norms of everyday life (cf. Holy and Stuchlik, 1983) and local knowledge were gained through joining in. Since the start of the volcano crisis in July 1995, periodic return visits in 2000, 2005, 2015 and 2017 have kept this research up-to-date and added a longitudinal aspect to living through a volcano natural disaster_with a high level of confidence in the interpretation of research material.

\section{INSERT TABLE. 1.0 HERE \\ Caption: Methodological pluralism as triangulation \\ Source: J. Skinner, 2017.}

Throughout the longitudinal research, key protagonists have been interviewed from bed and breakfast business owners to various -successive Directors of the Montserrat Tourist Board. The staff at the Montserrat National Trust have been liaised with eontinuouslyfrom 1994 to present. More recently, in 2015 and 2017, tour guides have been accompanied through Plymouth, and their trainers and certificators interviewed-specifically. Interviews have been semi-structured and based around themes ranging from support and criticism of 
tourism strategy, disaster resilience and regeneration, dark tourism and cultural heritage with transcripts searched for keywords and emerging themes. Finally, in this comprehensive research triangulation, updates were noted and filtered as - what Kozinets (2015) refers to as 'netnography' - by following tracking social media, digital news feeds and; online newsgroups, as well as and tracking key migrants from the island and residents relocated to the north of the island from 1995 to present. There is a coherence between each ofacross these primary and secondary research techniques with the material from each working to substantiate each other. Moreover, earlier research identified a similarity between the anthropologist's ethnographic research on the island and travel writers' fieldwork sponsored by the Montserrat Tourist Board (Skinner 2008); travel writing representations of the island inform the public and are informed by - visits to the island and so are appropriate media Though not strictly grounded theory, and approximating more the situational analyses approach updating on Geertzian (1973) interpretative 'thick description' (cf. Clarke, 2003), the data is similarly derived from the ground up until 'saturation' point (Glaser and Strauss, 1967) in the researcher when no new insights are generated from the data.-

\section{The buried city Plymouth, Montserrat}

Montserrat is a small British Overseas Territory in the Eastern Caribbean next to Antigua. It is shaped like a teardrop, measuring 7 miles in width and 10 miles in length, and had a working population pre-1995 of approximately 12,000, the majority descendants from those enslaved in the abhorrent sugar by slavery plantation institution practiced throughout the Caribbean until 1834. Governance of Montserrat traditionally resided in the federation of British Leeward Islands (1671-1958) with Antigua and Barbuda as one colony and St Kitts, Nevis, Anguilla and the Virgin Islands as the other. Plymouth has been the capital and main port of Montserrat and the seat of local government for approximately three hundred and fifty years, ever since the west of the island was developed by settlers post- 1650 . Whereas colonial settlement of the albeit uninhabited island is dated at 1632, island historian Sir Howard Fergus notes that the Plymouth goal bears an inscription, 'erected in 1664' (Fergus, 1994, p. 18). It has been described as 'Georgian-era' (Moran 2010) and quaint and quintessentially colonial British. The island was settled first by Irish indentured labourers and British plantation colonists and artisans. The influences have been lasting in terms of place names around the island (Kinsale, St Patrick's, Richmond Hill, Plymouth, Salem, O'Garros) and, contentiously, the suggestion that music, manners and ancestry are mixed to create a new 'Black Irish' ethnicity (Messenger, 1973, 1975). In her history of seventeenth and eighteenth century settler society in the English Leeward Islands, Natalie Zacek $(2010,98)$ distinguishes between the Irish farmer/settlers living outside of the capital around the island and the artisans living in the capital when she characterizes 'the hardscrabble small farmers of St. Patrick's and the struggling artisans and laborers who populated Plymouth'. Fast forward several hundred years to the mid-1990s and Plymouth is still full of artisans - plying their tourism trade, and there are some smallholding farmers still work their land in some parts of the island periphery. Journalist Phil Davison $(2003,4)$ describes the capital that I was familiar with all too well as 'the pastel toytown capital, Plymouth'. It lies at the base of some green tropical peaks, the Soufriere Hills - the significant endpoint of some deep ghauts that wend down the side of the hills to Plymouth 'like scratch marks' (Davison, 2003, 9).

Plymouth town, capital of the island, the "Plymouth past", had four streets running parallel to a harbour front where there was a war memorial tower with clock on top. Nestled in Sugar Bay, Plymouth port was a cargo port though with not enough deep water for large cruise ships. The town had a population of approximately 5,000 inhabitants with shops, a Texaco petrol station, Barclays Bank, law court and parliament buildings at its centre with 
Philatelic Bureau, radio station and Montserrat Secondary School, and hospital around the periphery. It was overlooked by Richmond Hill where an old windmill had been converted into a small national museum, and where the Montserrat Spring Hotel catered for island visitors. The Evergreen Roundabout was the main town intersection and meeting point or 'liming' spot (hangout) under a large ficus tree. Davison $(2003,10)$ refers to the spot, not inappropriately, as 'the symbolic heart of town, a small-scale Piccadilly Circus'. Since the Caribbean-wide devastation of Hurricane Hugo in 1989, when $150 \mathrm{mph}$ winds ravaged the | island and destroyed $95 \%$ of all the buildings on the island (SkinnerXxxxx, 2011), a new jetty was being constructed along with a new hospital and new Government Headquarters. July 1995 and a devastating volcano crisis began which is on-going to this day. Key markers for Plymouth town are:

- 21 August 1995 - tephra ejected from the volcano and fell over Plymouth

- December 1995 - temporary evacuation of Plymouth for several months

- 25 June 1997 - large eruption killing 19 Montserratians in the east of the island and producing pyroclastic flow in the east resulting in Plymouth's permanent evacuation

- 4-8 August 1997 - continued eruption burns and buries the town in $1.4 \mathrm{~m}$ ash leading to the abandonment of Plymouth, creation of an exclusion zone, and government relocation to Brades the de facto capital in the north of the island

- 2010 - sandmining begins in the evacuation zone leading to export via the Plymouth port jetty

- 2013 - a new port is constructed and land cleared for a new capital in the north of the island (Little Bay); though inaccessible, Plymouth remains the de jure capital of Montserrat

- February 2015 - Saga Pearl II visits Montserrat using Plymouth jetty

- 2017 - tour guide training for accompanied tours of Plymouth outskirts

Guardian journalist Polly Pattullo (2000a) published a detailed account of the natural disaster crisis on Montserrat in 2000: Fire From the Mountain: The tragedy of Montserrat and the betrayal of its people. The main title riffs off a popular nursery rhyme 'Fire in the mountain' that was used on Montserrat as the signal for the slave uprising in 1768 (Mullin, 1995, 219); it is also a Grateful Dead song that was allegedly being sung by the band on 12 June 1980 in Portland, Oregon, when nearby Mt St Helens had a secondary eruption. She translates and evokes the volcano crisis, from 1997 in particular, when, pre-eruption, in her chapter on 'The Day of Death', the volcano dome was had grown by May in volume 65 million cubic metres, 'the equivalent of a bonfire piled with 65 million sacks' (Pattullo, 2000a, 5). By December, it had doubled in size, leading to a Boxing Day collapse of some 46 million cubic metres of material. Still the dome grew until magma stopped reaching the surface in March 1998, leaving the dome's height at 1000 metres, with 300 million cubic metres of new rock poised over the south of the island - 'enough to fill 3000 Royal Albert Halls' Pattullo (2000a, 84) explains. Pattullo notes the attraction of the volcano for residents as well as visitors, especially the son et lumiere explosions at night: 'Fiery-red rocks cascaded from the summit with theatrical exuberance' (Pattullo, 2000a, 82). Flying over the island, there is an unrecognizable 'sea of blankness' (Pattullo, 2000a, 83) as landmarks become entombed. Ash covers everything 'as in the aftermath of a polluted snowstorm' (Pattullo, 2000a, 27); heated pyroclastic flows burn and bury all before it. Plymouth is reported upon in the international press as a tropical version of Pompeii, again a moniker translated for the Old World, just as the island had been marketed previously as 'The Emerald Isle of the Caribbean': 'Plymouth was written about as if it had become a post-nuclear war zone or - the most popular invocation - a tropical Pompeii' (Pattullo, 2000a, 87). Presciently, Pattullo adds that modern day disasters are unlikely to be left as ruins. Rather, their magnitude preserves them as ghoulish tourist attractions in themselves: 'our way is to turn the 
ruins into a heritage site. Tourism is the way the Caribbean makes its living' (Pattullo, 2000a, 88). In this way the science fiction-like eeriness of Montserrat with the foreboding of the volcano becomes the attraction. In his recent USA Today article, Mysterious Montserrat: Volcano-buried city, Beatles legacy, journalist Mark Rogers (2016) refers to the island as 'beautiful and mysterious', practically the modern-day setting for Dr Moreau, or 'the set of a | 1960s episode of The Twilight Zone'.

Pattullo (2000b) extends her documentary of the natural disaster into a critique of British colonialism as the UK government and development workers adopted 'wait and see' approach to the creeping culpabilities of the volcano. This was a hot mix of despair and denial that resulted in further evacuation to the north and overseas, and culminated in protest against the UK government. Plymouth had become an 'ash-ridden ghost-town' (Pattullo 2000b). Five years later, and Pattullo reports from Plymouth of a Montserrat rebuilding itself, luring back its evacuees, a volcano broadly stable and "simmering". Plymouth is unrecognizable, quite literally lost to lava and with few features beyond submerged buildings, many now swallowed completely. 'Plymouth is gone, except as a 21 st-century Pompeii-style tourist attraction', writes Pattullo (2005), confirming her tourist proposition from five years earlier. Plymouth is now a dead town, buried, but visited by mourners and the morbid, souvenir hunters and those seeking schadenfreude. Pattullo's (2005) update opens as follows:

John Wilson, Montserrat's Minister of Communications and Works, is standing on top of 40ft of lava in his island's capital, Plymouth. Beneath his feet are buried streets and buildings. The aquamarine sea edging this now dead town and the minister's turquoise shirt are the only spots of colour in a monochrome landscape. The grey vista of rubble, ash and boulders is the product of the Soufriere Hills volcano, whose first recorded eruption plunged this tiny eastern Caribbean island into crisis exactly 10 years ago.

This is the new normal that the islanders in the north have come to terms with, evincing a resilient necessity. They have moved on from the 'living with the unexpected' phase (cf. Possekel 1999) associated with the late nineties. Pompeii is still the adjective for Plymouth, a 'nickname' for the evacuation zone according to Irish Times journalist Lorna Siggins (2016), but it is mixed with reports of recovery and reconstruction. David Whitely (2013) accounts for Plymouth whilst writing about the new capital 'city' in the north on the 'volcano-ravaged island': 'Plymouth is a modern day Pompeii, completely buried and burned out. It can now only be seen by boat tour or from the top of one of the hills that overlook it; the views offering a heart-in-mouth picture of nature's destructive force.' The views are both sensational and sublime. The contrast across the island, Atlas Obscura (2013) describes 'Half Paradise, Half Mud-Drowned Wasteland' - are extremes that appeal to the tourist seeking difference in their travel experiences. Mangold (2016) suggests that tours to Plymouth 'ghost town' can save the island, as tourists are attracted to the barely recognizable 'skeletal remains' still accessible such as the Montserrat Springs Hotel; the contrast is between part of 'an island in aspic' and the sumptuous vegetation and breathtaking views on the other side of the island. This island is 'rising from the ashes' (Mangold, 2016), a naturalistic post-disaster 'Pheonix tourism' as opposed to post-conflict 'Pheonix tourism' (cf. Causevic and Lynch, 2011) coined from tourist visits to Sarajevo. The recovery phase is to use this new set of resources, to turn 'ash to cash' around this 'modern Pompeii slowly being reclaimed by the mountain' (Schuessler, 2016). This is by investing in geothermal energy, sand mining and tourism. These clean renewables, and the low-key non-mass tourism of 'lava-loving travelers', "volcanophiles" as some guest house providers refer to them (Bachelor, 2014), provide a counter to the narrative of post-apocalyptic disaster. The two sides of Montserrat can represent a utopia and a dystopia, with the erasure of the landscape exposing the civility and tenacity of Montserratian citizens rather than the ruined state or social breakdown portrayed on screen. Plymouth has become an apocalyptic amusement park for those. Here is precarity writ large. Tourists can stand outside of themselves as they

Formatted: Font: Italic, No underline 
holiday adjacent to the danger zone. This is a naturalistic alternative to any conflict 'holidays in the danger zone' (cf. Lisle, 2016); or the anti-advocacy of the environmental activist 'toxic tours' of polluted places (cf. Pezzullo, 2007).

\section{The apocalypse tour of Plymouth}

Ian Thomson (2012) describes Montserrat with apposite adjectives as 'a smoulderingly beautiful volcanic island'. He connects the city Plymouth to Pompeii with the characterisation that ' $[\mathrm{t}] \mathrm{he}$ lava-stricken south of the island presents a Pompeii-like spectacle of devastation'. This is reiterated with his guided visit to the Montserrat Springs Hotel, a haunted hotel on the outskirts of the city:

No one lives in this tropical Pompeii anymore. The Montserrat Springs Hotel, once glitzy, had rusted in parts and collapsed owing to exposure to corrosive volcanic gases, acid rain and ash fall. Its few remaining rooms had been left undisturbed: shirts hung ghostly in a wardrobe, and a club sandwich (I think) stood calcified on a dust-caked table. Cecil Wade, our guide, rightly saw a potential for "disaster tourism" but joked that the hotel was haunted by "jumbie" spirits, and urged us to leave. (Thomson, 2012)

Thomson visits Plymouth with one of the certified tour guides to the area, taxi driver and leather craftsman Cecil Wade. There he sees an overview of Plymouth's destruction from the terrace by the pool, and is able to explore some of the guest rooms - but no one is checking in anymore. The Montserrat Springs sits on Richmond Hill in Zone C, currently an unrestricted access zone. The view is of Zone V, a restricted access area. No one can stay for long in this part of the island: this part of the island - almost the entire southern half of the island includes the Soufriere Hills - is open to essential workers and 'Daytime access to some areas' only (MVO, 2011), and this is when the Hazard Scale is at its lowest (level 1: more than one year with no measured activity). Other parts of the island range between restricted and controlled access depending upon the hazard level scale of volcanic activity. To enter Plymouth necessitates special guide training, a permit from the Montserrat Police who will open the gates and accompany the visit, and continual radio contact with the Montserrat Volcano Observatory. Technically, when tourists are shown authorized parts of Plymouth, their vehicle is pointed in the direction of evacuation and left with the engine running, and the accompanying police officer ensures that tourists are continually within their sight lines. Typically, a day tour begins in Little Bay port, picking the tourists up from the ferry and driving through the emerging new capital; tours can depart to the east to the new airport and new accommodation, and on to Jack Boy hill viewing station overlooking the old airport and eastern flanks of the volcano where the tragic deaths occurred in June 1997. Returning to the west of the island, tours head south for the exclusion zone, driving across Belham Valley (an expatriate accommodation region and former 18 hole golf course now destroyed by volcanic lahar). Climbing out of the southern side of the valley one passes the first abandoned ruins of houses in the exclusion zone, and the high levels of ash cleared to make access down towards Plymouth. Tours of the outskirts concentrate on the Montserrat Springs Hotel, an open abandoned decaying hotel with a pool full of debris, rooms for view, and a balcony panoramic of the volcano and its vista of destruction. With permits, tours can continue to sample parts of Plymouth leading towards the former capital's jetty. This is where some island ferries dock temporarily to being their tours of the island. Leaving the evacuation zone, day trippers can return passing the ruins of the iconic recording studio Air Studios, the expatriate villas of Old Towne and regenerated Vue Pointe hotel and climb Mongo Hill to visit the Montserrat Volcano Observatory. If the visitors are a large group from a neighbouring Caribbean island such as Guadeloupe, they might have a sea bath and picnic in Woodlands Bay to refresh themselves. Expatriate tourists are generally small group or family tourists who are invited to have a lunch at a local restaurant in Old Towne. 
Keri Jones (2016) is a photo-journalist who took one of Sun's Montserrat Island Tours in 2016. She is returning to the island after an ashen visit in 2010. Plymouth, for her, is a 'deserted city, mothballed in metres of ash and boulders'. Jones prefaces her visit with an interview with Rod Stewart, Director of the MVO. Thus, before visiting Plymouth, she presents the reader with facts about the speed and danger of the volcano that can erupt and eject rock and gas at speeds in excess of $200 \mathrm{mph}$. This makes her anxious when they reach the Exclusion Zone V where they wait for the police to let them enter on a timed visit. It is the anti-thesis to a visit to a theme park. It is 'not Disneyland' for all the surrealness Jones may be feeling. The contrast in her environment is stark, driving along roads surrounded by thick foliage before turning the corner to see the volcanoscape:

The tunnel of trees and foliage around us was green and verdant and gave no hint of our proximity to the site of a natural disaster. We passed an abandoned school and petrol station buildings and then, turning the corner, I saw the intimidating and towering volcano - a view I will never forget.

I had seen pictures of this vibrant, colourful colonial town in years gone by. Plymouth had looked lovely, with its mix of traditional, garrison-style stone buildings and wooden villas. The view before me resembled the aftermath of a nuclear attack. (Jones, 2016)

Jones feels that she is living through an apocalyptic encounter in close-up. This part of the island has been turned into 'a wasteland', roads 'redrawn', landscapes re-sculpted.

The whole scene was one of devastation. You could make out the shape of buildings, still standing but with windows broken. The ash was deep and compacted. Some structures only had their upper levels visible. In other buildings you could peer inside but there was only two or three feet of space between the ash and the ground floor ceiling. More buildings were bent out of shape by the huge boulders, which had rained down on the former capital. (Jones, 2016)

They visit Angelos supermarket, the outside visible from the first floor up, and the inside viewed through the top of what were high entrance windows. On a tour with Sunny, myself and a visiting tourist were shown the empty aisles inside and a lone fan spinning in the breeze. Sunny has some melted glass tucked behind the top of the window to show tourists the intense heat that came with the pyroclastic flows. The Montserrat policeman keeps close to us for safety, and Sunny keeps his sightline to the vehicle. We pass offices with no walls, but wall planners hanging in the wind. Tourist graffiti is etched onto the outside of some of these buildings. It is as Jones (2016) describes: 'Life, as it was in 1997, has been mothballed in ash and debris. You could see office wall planners and calendars stuck on that date.'

A lot of Buried City tours visit the Montserrat Springs Hotel to the north of Plymouth, overlooking the sad eeriness of the 'volcano-buried city' (Rogers, 2016). This hotel used to be a thriving weekend spot with tennis courts, spa and Lou's beach bar. It was where expats caught up on the news and gossip. In a recent visit to the hotel with Sunny's father, David Lea, part-time travel journalist Phil Sites (2014) thought the rooms 'brimming with various plants and wildlife' - a scene from the film Jumanji. It is certainly disconcerting, with empty rooms, collapsing office furniture, fluttering hotel stationery and a silence and emptiness of human life reminding me of the science fiction films Stalker or The Andromeda Strain (SkinnerXxxxx, 2008). It is 'Silent Hill meets Hawaii 5.0' for urbex explorer Shane Thoms (2016) in his photo article Montserrat - 5 days in a modern Pompeii: Plymouth - Town of God. Thoms (2016) writes insightfully about his intentions and reactions to Plymouth and the hotel:

This was a privileged exploration with the intention to seek out the emotional traces that still lingered in this once thriving urban tourist space. Situated at the foot of a collapsing volcanic dome, this eerily barren, smokey landscape reveals the fragility of the human species and mother nature's spectacular ability to reclaim her environment.

Thoms photographs the sublime nature of the abandoned and ruined urban space. Montserrat lends itself to those seeking this counter-tourism, this Sun, Sea... and Sulphur as journalist Tweedie (2017) refers to it. Others, such as Capt Eric Bergeron (2016) - guided by Sunny Lea - with his professional interview documentary "Lost City of Plymouth", and illicit yacht crew of Sy Skye (2016) with their unsanctioned "Montserrat Volcano exclusion zone"

\begin{tabular}{l} 
Formatted: Font: Italic, No underline \\
Formatted: Font: Italic, No underline \\
Formatted: Font: Italic, No underline \\
Formatted: Font: Italic, No underline \\
Formatted: Font: Italic, No underline \\
\hline
\end{tabular}


(2016), film the site using drones and post to their YouTube channels, adding horror music to recreate the atmosphere they experienced. One of the key films covering Montserrat, Plymouth and the volcano is directed by David Seitz (2007a), exploring the island during its annual St Patrick's Day celebrations. Episode three of the YouTube documentary (Seitz, 2007b) - I make an unintentional cameo in episode five - walks through the Montserrat Springs Hotel, dwelling on the empty reception with room keys rusting into their place holders, the kitchens covered in ash and unusable, a toilet sunken into the flow of ash around | it, roof structures open to the elements (SkinnerXxxxx, 2016). Five minutes in, there is a shot of Plymouth and the volcano from the hotel terrace. There is stagnant water in the pool.

Ten years later and the pool has grown in with silt and ferns replacing the water. The water is in the view to the sea and now the tourist can walk on the 'once-was' water of the pool area (see Fig 1.0). Tour guides have turned this water feature for the tourism-past into a waterless feature of their present-day 'anti-tourists' (Edensor, 2005, p.95). Here modernity is in decay with the roof timbers falling in on itself. The swimming pool is no longer clearly delineated by its margins. Instead, the clear sharp lines come from nature's horizon rather than concrete leisure formations. The viewer can walk through this metaphor of capitalist decay, apocalyptic voyeurs capturing it through their camera lens. They don't have to live through it as Sunny has and is continuing to do so.

INSERT FIG. 1.0 HERE

Caption: Tour guide showing tourist the Montserrat Springs Hotel swimming pool before and after the volcano disaster

Source: Jxx. SkinnerXxxxx, 2017.

'Post-nuclear', to return to Tweedie (2006), this southern scape of Montserrat represents a more environmental dark tourism than the typical man-made genocide, Holocaust, or Ground Zero (New York/Hiroshima). Tweedie describes his visit to the Montserrat Springs as a queer, abnormal experience, one of contradiction in decomposition:

The pool is a swamp, and the darkened rooms, so carefully refurbished for a re-opening that never was, are half-filled with ash and dried mud. Used-up cheque books from a decade ago litter the floor around the reception desk, scattered by some unknown intruder. The switchboard, caked in dust, still waits for a call.

We walk along the ash beach under the beating sun, kicking up great clouds of fine white powder as we go. The air is hot and mildly sulphurous.

We could do with a drink but no bar opens in Plymouth. Only the waves break the silence; we are completely alone. (Tweedie, 2006)

There are phones that will never ring. There is a pool with a solid surface. There are refurbished new rooms - from the waist up. There are bars without drinks. And there are beaches that kick-up grey ash rather than golden sand. Around the Springs are other 'halfway houses', caught mid-collapse, some with graffiti on the window glass, fingerpainted signs of visitation if not habitation (XXXXX Skinner 2016). Mangold took the same Montserrat Islands Tour (MIT, 2017) that Sunny gives, enjoying the distortion and contradiction of the island where he could become the explorer:

Climb carefully down some cracked and broken steps and enter the reception area of the former four-star Montserrat Springs Hotel. Pendulum lights still hang drunkenly from the cracked ceiling, and perfectly legible old emails and telexes with reservation requests and confirmations litter the back office. (Mangold, 2016)

It is almost forensic as the journalist picks his way through the 'skeletal' remains' (Mangold, 2016). This 'volcano tourism' is, for Mangold (2016) the potential salvation for the island, whether it is by daytripppers from neighbouring islands arriving at Plymouth jetty to see the 
Springs Hotel before visiting the north of the island, ferry visitors staying to explore in private, or some way of harnessing the expensive helicopter tours business from neighbouring Antigua.

In his study of the attraction to industrial ruins in Britain, cultural geographer Tim Edensor (2005) makes the point that such ruins represent hybridity, alterity and fatality to the viewer. As urban ruins, these spaces and their debris are connected with dark tourism as examples of darkness and degeneration, a modern-day gothic sensibility illustrating the vulnerability and temporariness of the contemporary (cf. Edensor, 2005, p.13-14). The tourist views the ruin as different, exotic, alien, unstructured and no longer delineated. This presents a mortality to the tourist. 'The ruin marks an end, a sudden fatality' (Edensor, 2005, p.165) for the visitor. For Stone (2012), this dark tourism serves as a mediation point where tourists can - from a safe distance - experiment, rehearse, think through and play with their inevitable future. In this 'space of defamiliarisation' (Edensor, 2005, p.25), where the everyday has become extraordinary, the tourists are exploring under the safe guidance of Sunny. He clears a path to the Springs's rooms, and lets them wander, pointing out the head clearance and the ash that sinks underfoot as we walk over a sofa. It is semi-'improvisational pathmaking' (Edensor, 2005, p.87) with our 'pathfinder' (Cohen, 1985).

\section{The dark tourism city?}

For the purposes of this Special Issue on Dark Tourism and Cities, we need to ask two questions about the preceding case study: is Plymouth, Montserrat, a city? And is Plymouth Montserrat - and the Montserrat Springs an example of dark tourism? Plymouth is referred to directly as both a town and a city. It has not been described or defined as a dark tourism destination, though the island Montserrat, as a whole, has. With respect to both topics, there are supply and consumption perspectives that can be taken. They differ in terms of marketing and expectation, and delivery and reality experienced. Disciplinary orientation also plays its part such as in Hannerz's (1980, pp.59-118) section 'The Search for the City' in his treatise on urban anthropology when he looks at "when is the city?" Rather than take a numerical definition, he looks to social sciences and the Chicago School of Sociology in particular, pointing out that the city is a space of heterogeneity where labour and social relations are more specialized and less kinship dependent - organic, to use Durkheim's term. Plymouth, Montserrat, lacks the numerical density of a city, but it was qualitatively different to live in. It was the hub for the island; the centre of activity, governance, trade, tourism and industrial activity (radio station, rice milling plant, service stations and other industrial activity were based in the capital). It was not, however, ever the main reason for visiting the island. It is thus a different urban space for the tourist to the city break European destination where the city visited is the endpoint in itself. Plymouth was always the urban gateway and focalpoint of activity on the island.

Besides urbane and industrial reasons for linking Plymouth with the idea of the city, there are advertising and journalistic points of association. The official Visit Montserrat website managed by the Montserrat Tourist Board promotes visits to Plymouth the former capital, a town. But its URL and its definition for the visit is one of Plymouth 'Buried City': http://www.visitmontserrat.com/buried-city/ (MTB, 2017). The abandonment and decay seen is not dissimilar to Liverpool's wastelands regenerating naturally for Les Roberts (2011). These are spaces of an urban imaginary, psychogeographic spots that archive the dark city as what once was, palimpsests from the past. Roberts $(2011,317)$ draws our attention to the heterotopic nature of these environments. There are layers of meaning in these spaces of otherness. The Montserrat Springs has dense temporal difference to it: it is a version of its former self, ghosting the past, tracing or 'pouncing' the present. Either Plymouth present is a 
dystopia to the Plymouth past, or it is a stark contrast to north of the relatively utopic north of Belham Valley, 'the green and the gritty' coined by the Montserrat Tourist Board in their | former marketing campaigns (SkinnerXxxxx, 2015b). Plymouth is, for the tourist, an example of dystopian dark tourism (DDT), 'a dystopian world - utopianism gone awry' (Podoshen et al., 2015, p. 324). This is not, however, the simulated dystopianism of a tour of killer or black metal concert examined by the authors in Western environments. Here, on Montserrat, the aesthetics are scarcely constructed for the tourist. The scene of alienation is not on a screen painting or film screen. The confrontation is with a city buried by crisis, but preparation for a future shock, nevertheless, according to the authors. The magnitude, its scale, puts it also on a world stage equivalent to volcanic eruption in historic Pompeii, earthquake and tsunami devastation in early Modern Lisbon, hurricane disaster in contemporary New Orleans.

Lastly, Plymouth, Montserrat, is treated and experienced as a city, if now former, buried, lost. Reffes (2016) walks the 'lunar landscape' with her guide Norman Cassell, reporting on the 'buried city' as it is described by herself and Hon. Delmaude Ryan, Monserrat's deputy premier. Plymouth is 'Montserrat's capital city', for Bachelor (2014) and Harris (2017); 'ruined capital city', for Handy (2017); 'volcano-buried city' for Rogers (2013). Melan Mag Editor in Chief Joy Joses cites Plymouth as a city of the Caribbean in her ten reasons for visiting the island:

A Modern-Day Pompeii - Montserrat's now - buried capital city, Plymouth, has been compared to a modern-day Pompeii, minus the fossilized bodies. As the only volcanic-buried city in the Americas,

Plymouth offers visitors the rare chance to witness a city frozen in time. Visitors wishing to access the city may do so through a certified tour operator. (Joses 2017)

In all of these articles, Plymouth is advertised as a former city, as the capital and urban centre of the island. It exists on the 'gritty' side of the island and contrasts with the 'green' side of the island that is without a city - the once-proposed but unbuilt 'Port Diana', suggested after the death of Princess Diana in 1997. This is the yin and yang of the island with its contrary environments. As Kimball (2017) describes it: 'Montserrat today is actually two islands: there is the Safe Zone, to the north, which is lush and green; and the southern Exclusion Zone, which looks like a sepia-toned photograph.' This has implications for the marketing of the island: Director of Tourism Anita Nightingale (AnonMontserrat Tourist Board-, 2015) constructed a marketing position stressing this contrast with the 2015 strapline "Go Off the Grid; Explore the Green and the Gritty", and the explanation that Montserratians are like their island with a soft side and a harsh and resilient side. This 'geography of contrasts' (AnonMontserrat Tourist Board-, 2015) did not last long with Montserrat's marketing line being seen as too restrictive and appealing only to the adventurer. It was changed in 2017 to "Come. We have time for you."

With respect to the second issue of whether or not this tourism experience and/or its marketing constitutes dark tourism, it is possible to examine both supply and demand perspectives, as well as the definition of dark tourism itself. In terms of a grand scale dystopian environment dramatically altered by disaster, Montserrat and more specifically Plymouth meets the criteria of dark tourism island destination. It is not a site of atrocity, but one of disaster plus death. It is also a mediatized venue with extensive visual coverage in the news media and social media. Even the Montserrat Tourist Board is complicit in the marketing of the ash weary buried city/town of Plymouth. As such, Montserrat is a dark tourism, one massified by technological intervention like the growth of the volcano itself. It suffers from tourist interest in 'death, disaster and atrocity' product (cf. Lennon and Foley, 2004 , p. 3) whether the tourist is morbidly interested, wants a different adventurous experience, or a warning engagement with forthcoming apocalypse or their inevitable demise. Further to this, whilst there is no connection made to atrocity on the island - for all the barbarity and abuses of the slave plantation system - the tour guides do sometimes make 
reference to those missing from the community, or those lives lost in aeroplane crashes into the Soufriere Hills mountains or offshore the former airport or, most tragically, the rescue attempts made during and after the fatal collapse of the dome and subsequent pyroclastic flow down the eastern flank of the volcano on 25 June 1997. The viewing platform from Jack Boy Hill allows the visitor to picture the spread of the destruction of the volcano down the sides of the mountain, over villages and across the island's former runway into the sea (see Fig. 2.0).

\section{INSERT FIG. 2.0 HERE}

Caption: Tour guide explaining pyroclastic flows across eastern Montserrat to tourist, Jack Boy Hill viewing facility.

| Source: *. Xxxxx.. Skinner, 2017.

This is a dramatic account of death and survival, injury and warning. Like in Plymouth, the tops of buildings pock the dead ash landscape. The imagination emplots one into the narrative, empathizing with the past, perhaps testing the future, and recalibrating the present as the tourist returns to the soft green side of their stay - though, to be fair, one account of the airport disasters and deaths that I was party to immediately preceded the tourists' flight off the island.

The travel writers and journalists are very aware of the deaths on Montserrat when they write their pieces. It provides the scary backdrop for their explorations. The apocalypse is continuing and, with an element of frisson, the viewer could get caught up in it if they are not careful. Before entering Zone V with her guide Sunny, Keri Jones visits the Montserrat Volcano Observatory to speak with the Director and learn about how dangerous pyroclastic flows can be:

He doesn't take his duties lightly. The major blast in 1997 killed 19 people. It followed two years of volcanic activity and Rob says the tragedy might have been avoided if people had followed evacuation orders. Montserrat's volcano isn't one of those cones that just exudes hot lava and gases. It's potentially lethal because of pyroclastic flows and surges - the kind that are now known to have destroyed Pompeii in Roman times. (Jones, 2016)

Sites (2014), Bachelor (2014) and others use the deaths as part of their introduction to the island, setting the scene before the visit to Plymouth. Reffes (2016), however, makes no mention of the deaths. And Schuessler (2016) mistakenly attributes only nine deaths from the volcano. Peter Hohenhaus (2016), who runs the popular Dark-Tourism.com website, returns us to the 'Pompeii' name or label that has become a metonym for volcano disasters in general. It applies to Plymouth where there has been a slow gradual burial of the capital.

Continuous lahars have since contributed to the gradual burial of the once thriving centre of life on

Montserrat. It is now a "modern-day Pompeii" (they do call it that even in the mainstream tourist brochures!) - and thus is the main draw for the dark tourist. (Hohenhaus, 2016)

Whilst there have been no recorded deaths in Plymouth itself, the deaths on the island have been wrought by the same volcano and its eruptions. This, then, is a deathly dark tourism destination by association for Hohenaus. The dark tourism label depends upon the extent or range of the mortality. Lightening the shadows of Plymouth, geotourism scholars Petford et al. (2010, p. 91) refer to Plymouth as 'in effect a modern-day Pompeii minus human casualties'. Certainly no casualties of the eruption from Plymouth are advertised for the searching and interrogating that visitors do in the Springs Hotel or down on the ground, the new surface that Plymouth has. 


\section{Conclusion}

This paper has shown that, though not of Pompeiian proportions, Plymouth is a dark tourism destination as a place of disaster, and as, potentially and by presumed association, a place of death. It is a 'shadowzone' of dark travel as conceptualized by postcolonial critics Clarke, Dutton and Johnston (2014), 'a site traumatized by colonialism and its aftermath' (Clarke, Dutton and Johnston, 2014, pp. 221-222) compounded by natural disaster. It has shown in detail the guiding around Plymouth and its perimeter where the Montserrat Springs Hotel commands attention over the ghost town/city. Often this disaster space is conceptualised and narrated in the terms of the viewer, and frequently compared to a film that they have seen from popular horror such as The Shining or entertainment as in Jumanji, to post-apocalyptic The Stalker. Equally the politics of the protagonist feature in how they interpret the landscape as a natural place of awe as eco-criticism (cf. Carrigan, 2011$)$ or capitalist decline - a foreboding and forewarning. So too, there is an attraction to the post-apocalyptic, to the emphatic and clear-cut in a fluid world. The dark traveler, whether journalist or tourist, is visiting Montserrat after the event, attracted to its spectacular magnitude that they go about sensationalising. They are viewing a new landscape which has an emancipatory potential about it for all its destructiveness. It has a freedom, then, to be advertised in different directions: dark, gritty, apocalyptic, Pompeiian. As an empty landscape, the no-go area where tourists now go has become a city break destination with a difference. In her study of post 9/11 apocalypse narratives, Apocalypse and Post-Politics: The romance of the end (2012), This, political theorist Mary Manjikian ( $(\overline{2} \overline{1} \overline{2})$ suggests is 'the romance of the end'examines the public fascination with the end of things, the end of times. This apocalypse as Armageddon or Eden is played out on Montserrat. Here, the ruins of the city are revealed to the visitor, and urban society is re-narrated. But it is an orderly affair showing that a natural disaster can destroy the physical place but that the social practices and conventions of society are not necessarily lost. Manjikian (2012, p. 228) declares the apocalyptic narrative a decentering narrative and oddly British and post-colonial in feel. This is because there is a nostalgia for the 'old life', pre-Modern, pre-industrial and pre-urban, an impulse found especially in the United States. Ironically, this nostalgia is attracting US tourists to urban Montserrat where one can experience the similar effects of colonization and natural disaster. The land in southern Montserrat is thus doubly aAs in colonialist practices, in a naturat disaster, the land is being cleared creating a terra nulla -in southern Montserrat. YetIn apocalyptic dark tourism, at least, this no man's land is no longer a no-go area as tourism's leisure periphery pushes back against the volcano.

\section{References}

ABTA (2016), ABTA Holiday Habits Report 2016, London: ABTA Ltd. https://abta.com/assets/uploads/general/2016_Holiday_Habits_Report.pdf (accessed 14 June 2017).

ABTA (2013), "City breaks now as popular as beach holidays", ABTA press release, https://abta.com/aboutus/press/city-breaks-now-as-popular-as-beach-holidays (accessed 14 June 2017).

Anon. (2016), "With a new airport, Montserrat's simmering voleano and intriguing Pompeii in the Tropies are more accessible than ever", Caribbean Travel Website, September 2016, http://www.caribbeantravel.com/caribbean-islands/montserrat (accessed 17 June 2017).

Anon. (2015), "Get Off the Grid to Montserrat", Montserrat Tourist Board press release, http://www.cruiseindustrynews.com/cruise-news/12317-get-off-the-grid-to-montserrat.html (accessed 22 May 2015).

Anon. (2003), "Unfavourable Promotion of Montserrat", Letter to the Editor, The Montserrat Reporter 20 June 2003, http://www.montserratreporter.org/news/member/letters.htm (accessed 17 June 2016) referring to unsaved Lonely Planet description of Montserrat https://www.lonelyplanet.com/montserrat (accessed 17 June 2017). 
Bachelor, Blane (2014), "Montserrat: a modern-day Pompeii in the Caribbean", Fox News, 20 February 2014, http://www.foxnews.com/travel/2014/02/20/montserrat-modern-day-pompeii-in-caribbean.htm (accessed 1 September 2016).

Bergeron, Capt E. (2016) "Lost City of Plymouth Montserrat", Capt Eric Bergeron YouTube Channel, https://www.youtube.com/watch?v=t9F-ws8T0Jw (accessed 5 February 2017).

Biran, A. and Poria, Y., (2012), "Re-conceptualizing dark tourism", in Sharpley, R. and Stone, P. (Eds) The contemporary tourist experience: Concepts and consequences, Routledge, London, pp. 57-70.

Bowman, M. and Pezzullo, P. (2009), "What's So 'Dark' about 'Dark Tourism'? Death, Tours, and Performance", Tourist Studies, Vol. 9 No.3, pp. 187-202.

Buda, D. (2015), "The death drive in tourism studies", Annals of Tourism Research, Vol. 50 No. 1, pp. 39-51.

Caribbean Travel Website. (2016), "With a new airport, Montserrat's simmering volcano and intriguing Pompeii in the Tropics are more accessible than ever", Caribbean Travel Website, September 2016, http://www.caribbeantravel.com/caribbean-islands/montserrat (accessed 17 June 2017).

Carrigan, A. (2011), "(Eco)catastrophe, reconstruction, and representation: Montserrat and the limits of sustainability", New Literatures Review, No. 47-48, pp. 111-128.

Causevic, S. and Lynch, P. (2011), "Phoenix Tourism: Post-Conflict Tourism Role", Annals of Tourism Research, Vol. 38 No. 3, pp. $780-800$

Clarke, A. (2003), "Situational Analyses: Grounded Theory Mapping After the Postmodern Turn", Symbolic Interaction, Vol. 26 No. 4, pp. 553-576.

Clarke, R. Dutton, J. and Johnston, A. (2014), "Shadow zones: dark travel and postcolonial cultures", Postcolonial Studies, Vol. 17 No. 3, pp. 221-235.

Cohen, E. (1985), "The Tourist Guide: The Origins, Structure and Dynamics of a Role", Annals of Tourism Research, Vol. 12 No. 1, pp. 5-29.

Cohen, S.A. and Gössling, S. (2015), "A darker side of hypermobility", Environment and Planning, Vol. 47 No. 8, pp. 166-1679.

Davison, P. (2003), Volcano in Paradise: Death and Survival on the Caribbean Island of Montserrat, London, Methuen.

Edensor, T. (2005), Industrial Ruins: Space, Aesthetics and Materiality, Oxford, Berg.

Fergus, H. (1994), Montserrat: History of a Caribbean Colony, London, Macmillan Caribbean.

Frenzel, F. (2013), "Slum tourism in the context of the tourism and poverty (relief) debate", Die Erde, Vol. 144 No. 2, pp. 117-128

Frew, E. and White, L. (2013), "Beyond the dark side: Research directions for dark tourism", in L. White, L. and E. Frew (Eds), Dark Tourism and Place Identity: Managing and Interpreting Dark Places, Oxon, Routledge, pp. 276-28̄

Geertz, C. (1973), The Interpretation of Cultures: Selected Essays, New York, Basic Books.

Glaser, B. and Strauss, A. (1967), The Discovery of Grounded Theory: Strategies for Qualitative Research, London, Weidenfeld and Nicolson.

Handy, G. (2017), "Montserrat celebrates its Irish roots", BBC News, 22 March 2017, http://www.bbc.co.uk/news/world-latin-america-39341211 (accessed 22 March 2017).

Hannerz, U. (1980), Exploring the City: Inquiries Toward an Urban Anthropology, New York, Columbia University Press.

Harris, P. (2017), "Party time under the volcano: St. Patrick's Day on Montserrat", The Boston Globe, 10 March 2017, http://www.bostonglobe.com/lifestyle/travel/2017/03/09/party-time-under-volcano-patrick-daymontserrat/cQpspOXR1z4Bb7O04cunNK/story.html?event=event25 (accessed 17 March 2017).

Heesen, R., Bright, L.K. and Zucker, A. (2016), "Vindicating methodological triangulation", Synthese, online first: https://doi.org/10.1007/s11229-016-1294-7 (accessed 1 November 2017).

Hepburn, S. (2012), "Shades of Darkness: Silence, Risk, and Fear among Tourists and Nepalis during Nepal's Civil War" in, XxxxxSkinner, J. (Ed.), Writing the Dark Side of Travel, Oxford, Berghahn Books, pp. $122-142$.

Hohenaus, P. (2016), "Montserrat”, Dark-Tourism.com, http://www.dark-tourism.com/index.php/montserratwest-indies (accessed 22 August 2016).

Holy, L. and Stuchlik, M. (1983), Actions, norms and representations: Foundations of anthropological inquiry, Cambridge, Cambridge University Press.

ITB (2015), ITB World Travel Trends Report 2015/2016, Munich: IPK International, http://www.itbberlin.de/media/itbk/itbk dl all/itbk dl all itbkongress/itbk dl all itbkongress itbkongress $365 /$ itbk dl all itbkongress itbkongress365 itblibrary/itbk dl all itbkongress itbkongress365 itblibrary studi en/ITB World Travel Trends Report 2015 2016.pdf (accessed 14 June 2017).

Jack, E. and Raturi, A, (2006), "Lessons learned from methodological triangulation in management research", Management Research News, Vol. 29 No. 6, pp. 345-357.

Formatted: Font: 10 pt, Italic, Font color: Text 1

Formatted: Font: $10 \mathrm{pt}$, Italic, Font color: Text 1

Formatted: Font: $10 \mathrm{pt}$, Italic, Font color Text 1

Formatted: Font: $10 \mathrm{pt}$, Italic, Font color:

Text 1

Formatted: Font: $10 \mathrm{pt}$, Italic, Font color Text 1 
Jones, K. (2016), “I Visit Plymouth In Montserrat - The Caribbean's Modern-Day Pompeii”, Great Destinations Radio Show, http://greatdestinationsradioshow.com/2016/10/26/i-visit-plymouth-the-abandonedcapital-of-montserrat/ (accessed 20 June 2017).

Joses, J. (2017), “Celebrating St. Patrick's Day in Montserrat", Melan Mag, 16 March 2017, http://melanmag.com/2017/3/16/celebrating-st-patricks-day-montserrat/ (accessed 17 March 2017).

Kennell, J. and Powell, R. (2016), "Dark cities? Developing a methodology for researching dark tourism in European cities", in Tourism and Culture in the Age of Innovation: Second International Conference IACuDiT, Athens 2015. Springer Proceedings in Business and Economics, Springer International Publishing, Switzerland, pp. 303-319.

Kimball, K. (2017), "The Island of Montserrat", Travel+Leisure Magazine, undated article, http://www.travelandleisure.com/articles/under-the-volcano (accessed 23 June 2017).

Kozinets, R. (2015), Netnography: Redefined, London, Sage.

Lennon, J., and Foley, M. (2004), Dark Tourism: The Attraction of Death and Disaster, Padstow, UK, Thomson Learning.

Lisle, D. (2016), Holidays in the Danger Zone: Entanglements of War and Tourism, London, University of Minnesota Press.

Mangold, T. (2016), "The island rising from the ashes: Enjoying a tourism fightback on Caribbean volcano-hit Montserrat", The Daily Mail, 12 November 2016, http://www.dailymail.co.uk/travel/article3930032/The-island-rising-ashes-Enjoying-tourism-fightback-Caribbean-volcano-hit-Montserrat.html (accessed 23 June 2017).

Manjikian, M. (2012), Apocalypse and Post-Politics: The Romance of the End, Plymouth, Lexington Books.

Messenger, J. (1975), "Montserrat: The Most Distinctively Irish Settlement in the New World", Ethnicity, Vol. 2, pp. 281-303.

Messenger, J. (1973), “African Retentions in Montserrat”, African Arts, Vol. No. 4, pp. 54-57.

Miles, W. (2002), "Auschwitz: museum interpretation and Darker Tourism", Annals of Tourism Research, Vol. 29 No. 4, pp. 1175-1178.

Miller, D. and Gonzalez, C. (2013), "When death is the destination: the business of death tourism - despite legal and social implications", International Journal of Culture, Tourism and Hospitality Research, Vol. 7 No. 3, pp. 293-306.

MIT (2017) "Montserrat Island Tours", Sunny Lea tour guide website, http://montserratislandtours.com/ (accessed 2 May 2017).

Montserrat Tourist Board. (2015), "Get Off the Grid to Montserrat", Montserrat Tourist Board press release, http://www.cruiseindustrynews.com/cruise-news/12317-get-off-the-grid-to-montserrat.html (accessed 22 May 2015).

Montserrat Reporter. (2003), "Unfavourable Promotion of Montserrat", Letter to the Editor, The Montserrat Reporter 20 June 2003, http://www.montserratreporter.org/news/member/letters.htm (accessed 17 June 2016) referring to unsaved Lonely Planet description of Montserrat https://www.lonelyplanet.com/montserrat (accessed 17 June 2017).

Moran, T. (2010), "Plymouth, Montserrat: The City that was Destroyed by a Volcano", Urban Ghosts online Urbex journal, 16 March 2010, http://www.urbanghostsmedia.com/2010/03/the-city-that-wasdestroyed-by-a-volcano/ (accessed 20 June 2017).

Mullin, M. (1995), Africa in America: Slave Acculturation and Resistance in the American South and the British Caribbean, 1736-1831, Chicago, University of Illinois Press.

MTB (2017), "Explore", Montserrat Tourist Board website, http://www.visitmontserrat.com/buried-city/ (accessed 1 February 2017).

MVO (2011), "Soufriere Hills Volcano, Monserrat: Hazard Levels and Access Restrictions", hazard level system, http://www.montserratvolcanoobservatory.info/hazard-level-system/ (accessed 27 June 2017).

Obscura, A. (2013), “The Caribbean Island That's Half Paradise, Half Mud-Drowned Wasteland", Slate.com online new mazagine, http://www.slate.com/blogs/atlas_obscura/2013/10/07/montserrat the_caribbean_island that s_half_p aradise half_mud_drowned_wasteland.html (accessed 1 June 2017).

Pattullo, P. (2005) "After the Volcano", The Guardian 18 July 2005, https://www.theguardian.com/environment/2005/jul/18/g2.naturaldisasters (accessed 24 June 2017).

Pattullo, P. (2000a), Fire From the Mountain: The Tragedy of Montserrat and the betrayal of its people, London, Constable.

Pattullo, P. (2000b), "Comment: Under the volcano", The Guardian, 5 May 2000, https://www.theguardian.com/comment/story/0,3604,217386,00.html (accessed 25 June 2017).

Petford, N., Fletcher, J. and Morakabati, Y. (2010) "On the Economics and Social Typology of Volcano Tourism with Special Reference to Montserrat, West Indies", in Erfurt-Cooper, P. and Cooper, M. 
(Eds) Volcano and Geothermal Tourism: Sustainable Geo-Resources for Leisure and Recreation, London, Earthscan Ltd, pp. 85-93.

Pezzullo, P. (2007), Toxic Tourism: Rhetorics of Pollution, Travel, and Environmental Justice, Tuscaloosa, University of Alabama Press.

Podoshen, J.2 Venkatesh, V., Wallin, J., Andrzejewski, S., and, Jin, Z. (2015), "Dystopian dark tourism: An exploratory examination", Tourism Management, Vol. 51, pp. 316-328.

Possekel, A. (1999), Living with the Unexpected: Linking Disaster Recovery to Sustainable Development in Montserrat, Berlin: Springer-Verlag.

Reffes, M. (2016), "Touring Plymouth, Montserrat, the Pompeii of the Caribbean”, TripSavvy website, 20 July 2016, http://gocaribbean.about.com/od/montserrat/ss/Touring-Plymouth-Montserrat-the-Pompeii-ofthe-Caribbean.htm\#showall (accessed 2 February 2-17).

Rittichainuwat, B. (2008), "Responding to Disaster: Thai and Scandinavian Tourists' Motivation to Visit Phuket, Thailand", Journal of Travel Research, Vol. 46, pp. 422-432.

Robb, E. (2009), "Violence and Recreation: Vacationing in the Realm of Dark Tourism", Anthropology and Humanism, Vol. 34 No. 1, pp. 51-60.

Roberts, L. (2011), "Regeneration, mobility and contested space: cultural reflections on a city in transition", in Harris, J. and Williams, R. (Eds), Regenerating Culture and Society: Art, Architecture and Urban Style within the Global Politics of City-Branding, Liverpool, Liverpool University Press, pp. 303-326.

Rogers, M. (2016), "Mysterious Montserrat: Volcano-buried city, Beatles legacy", USA Today, 5 July 2016, http://www.usatoday.com/story/travel/experience/caribbean/2016/06/28/montserrat/86437812/, accessed 1 September 2016.

Schuessler, R. (2016), “'Ash to cash': Montserrat gambles future on the volcano that nearly destroyed it", The Guardian, 28 January 2016, http://www.theguardian.com/world/2016/jan/28/montserrat-volcanobritish-territory-geothermal-energy-tourism-sand-mining (accessed 30 January 2016).

Seaton, A. (2009), "Thanatourism and its discontents: an appraisal of a decade's work with some future directions", in Tazim, J. and Robinson, M. (Eds), The Sage handbook of tourism studies, Sage, London, pp. $521-542$.

Seaton, A. (1996), "Guided by the dark: from thanatopsis to thanatourism", International Journal of Heritage Studies, Vol. 2 No. 4, pp. 234-244.

Seitz, D. (2007a) "Montserrat: Emerald Isle of the Caribbean (Part 1 of 9)", https://www.youtube.com/watch?v=0v5iLqy9Ap8\&feature=player_embedded (accessed 5 May 2009).,

Seitz, D. (2007b) "Montserrat: Emerald of the Caribbean (Part 3 of 9)", https://www.youtube.com/watch?v=Pg4K3Lef5_Q (accessed 5 May 2009).

Siggins, L. (2016), "The Caribbean Irish: the other Emerald Isle", The Irish Times, 16 April 2016, http://www.irishtimes.com/life-and-style/generation-emigration/the-caribbean-irish-the-other-emeraldisle-1.2610681 (accessed 15 August 2016).

| Sites, P. (2014), "How not to be a typical tourist: Visit Montserrat", The Weekend Roady website, 2 April 2014, https://weekendroady.com/2014/04/02/how-not-to-be-a-typical-tourist-visit-montserrat/ (accessed 24 July 2017).

| XxxxxSkinner, J-. (2016), “'Was here”: identity traces and digital footprints as survival writing', Terror on Tour - Special Issue, Liminalities: A Journal of Performance Studies 12(5), http://liminalities.net/125/washere.pdf.

Xxxxx, ,------ (2015a), "The Ambivalent Consumption of St. Patrick's Day amongst the Black Irish of Montserrat", in XxxxxSkinner, J. and Bryan, D. (Eds), Consuming St. Patrick's Day, Newcastle upon Tyne, Cambridge Scholars Publishing, pp. 186-208.

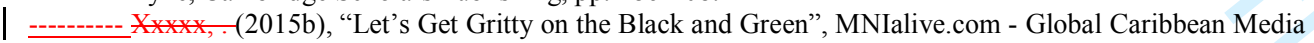
online news, 21 May 2015, http://www.mnialive.com/articles/let-s-get-gritty-on-the-black-and-green (accessed 21 May 2015).

| ---_-_- Xxxxx, (2011), "A Distinctive Disaster: Montserrat island under pressure" in, Soares, A. and McCusker, M. (Eds), Islanded Identities: Constructions of Postcolonial Cultural Insularity, Amsterdam, Rodopoi, pp. 63-89.

| --_-_XXXXX, . (2008), "Ghosts in the Head and Ghost Towns in the Field: Ethnography and the Experience of Presence and Absence", Journeys: International Journal of Travel and Travel Writing, Vol. 9 No. 2, pp. $10-31$.

| ------_Xxxx, . (2004), Before the Volcano: Reverberations of Identity on Montserrat, Kingston, Jamaica: Arawak Publications.

Stone, P. (2012). "Dark tourism and significant other death: towards a model of mortality mediation", Annals of Tourism Research, Vol. 39 No. 3, pp. 1565-1587.

Stone, P. (2006), "A dark tourism spectrum: Towards a typology of death and macabre related tourist sites, attractions and exhibitions", Tourism, Vol. 52 No. 2, pp. 145-160.
Formatted: Font: $10 \mathrm{pt}$, Italic, Font color: Text 1

Formatted: Font: $10 \mathrm{pt}$, Italic, Font color: Text 1 
Strange C., and Kempa, M. (2003), "Shades of Dark Tourism: Alcatraz and Robben Island", Annals of Tourism Research, Vol. 30 No. 2, pp. 386-405.

Sy Skye (2016), "Montserrat Volcano exclusion zone. Drone footage 2016 Sy Skye", Sy Skye YouTube Channel, 17 May 2016, https://www.youtube.com/watch?v=6MzVYnBtkR8 (accessed 25 July 2017).

Thoms, S. (2016), "Montserrat - 5 days in a modern Pompeii: Plymouth - Town of God", ShaneThoms website, undated, http://www.shanethoms.com/\#! shane-thoms-visual-journal/c1lsn (accessed 16 May 2016).

Thomson, I. (2012), "Montserrat Notebook", The Spectator, 7 January 2012, http://www.spectator.co.uk/features/7546618/montserrat-notebook/ (accessed 1 June 2014).

Tweedie, N. (2006) "Sun, sea ... and sulphur", The Telegraph, 25 February 2006, http://www.telegraph.co.uk/travel/sunandsea/734651/Sun-sea...and-sulphur.html (accessed 24 July 2017).

Whitely, D. (2013), "How a volcano-ravaged island is building itself a new capital city", Grumpy Traveller website and blog, http://www.grumpytraveller.com/2013/03/28/montserrat-volcano-new-capital/ (accessed 23 June 2017).

Willis, E. (2014) Theatricality, dark tourism and ethical spectatorship: absent others, New York, Palgrave Macmillan.

Zacek, N. (2010), Settler Society in the English Leeward Islands, 1670-1776, Cambridge, Cambridge University Press.

Zeiderman, A. (2006), The Fetish and the Favela: Notes on Tourism and the Commodification of Place in Rio

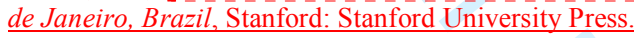

Formatted: Font: $10 \mathrm{pt}$, Italic, Font color: Text 1

Formatted: Font: $10 \mathrm{pt}$, Italic, Font color: Text 1

Formatted: Font: $10 \mathrm{pt}$, Italic, Font color: Text 1 


\begin{tabular}{|c|c|c|c|}
\hline Research Method & Rationale & Use & Results \\
\hline $\begin{array}{l}\text { Participant } \\
\text { observation }\end{array}$ & $\begin{array}{l}\text { A particularly involved } \\
\text { in-person, naturalistic } \\
\text { research method } \\
\text { enabling the } \\
\text { researcher to identify } \\
\text { and fathom local } \\
\text { issues and knowledge, } \\
\text { and to be able to } \\
\text { distinguish } \\
\text { presentation from } \\
\text { privately held beliefs } \\
\text { and convictions. Time } \\
\text { consuming but high in } \\
\text { validity. }\end{array}$ & $\begin{array}{l}10 \text { months on } \\
\text { Montserrat (October } \\
1994 \text { - July 1995); } \\
\text { follow-up short } \\
\text { research visits } \\
\text { (December 2000, } \\
\text { March 2005, March } \\
\text { 2015, April 2017). }\end{array}$ & $\begin{array}{l}\text { Extensive daily } \\
\text { fieldnotes, index } \\
\text { cards, newspapers, } \\
\text { radio recordings, } \\
\text { photographs and } \\
\text { video clips sifted for } \\
\text { themes. }\end{array}$ \\
\hline $\begin{array}{l}\text { Semi-structured } \\
\text { interview }\end{array}$ & $\begin{array}{l}\text { A refined but } \\
\text { contrived data } \\
\text { gathering technique } \\
\text { often used in one-off } \\
\text { encounters. Medium } \\
\text { level reliability but } \\
\text { highly useful and well } \\
\text { recognised soundbite } \\
\text { data. }\end{array}$ & $\begin{array}{l}\text { A complement to } \\
\text { participant } \\
\text { observation, } \\
\text { summarising research } \\
\text { issues with } 10 \text { key } \\
\text { informants, and used } \\
\text { in follow-up visits with } \\
\text { key individuals (tour } \\
\text { guides, Montserrat } \\
\text { Tourist Board, ZJB } \\
\text { Radio, Montserrat } \\
\text { National Trust). }\end{array}$ & $\begin{array}{l}\text { Transcripts searched } \\
\text { for keywords. }\end{array}$ \\
\hline Netnography & $\begin{array}{l}\text { A methodical } \\
\text { investigation into the } \\
\text { online social world } \\
\text { with synchronous and } \\
\text { asynchronous } \\
\text { engagement. Varying } \\
\text { degrees of reliability, } \\
\text { and archiving and } \\
\text { ethical permission } \\
\text { issues. }\end{array}$ & $\begin{array}{l}\text { Extensive continuous } \\
\text { online digital } \\
\text { ethnography } \\
\text { concentrating on } \\
\text { digital media and } \\
\text { social media content } \\
\text { from government and } \\
\text { news media sources, } \\
\text { and longstanding } \\
\text { contacts on Facebook } \\
\text { and the Electronic } \\
\text { Evergreen newsgroup. }\end{array}$ & $\begin{array}{l}\text { Digital archives } \\
\text { keyword searched for } \\
\text { relevant content. }\end{array}$ \\
\hline Discourse analysis & $\begin{array}{l}\text { The systematic meta- } \\
\text { analysis of the social } \\
\text { production of } \\
\text { meaning through } \\
\text { discourse interaction } \\
\text { (speech as text) and } \\
\text { non-discourse (text) }\end{array}$ & $\begin{array}{l}\text { Long term data mining } \\
\text { of archives, } \\
\text { publications, and } \\
\text { online media for } \\
\text { apocalyptic and dark } \\
\text { tourism references, } \\
\text { especially with respect }\end{array}$ & $\begin{array}{l}\text { Triangulation on the } \\
\text { research topic through } \\
\text { the analysis of the } \\
\text { various research } \\
\text { method materials. }\end{array}$ \\
\hline
\end{tabular}




\begin{tabular}{|l|l|l|l|}
\hline & for its structures and & to Plymouth. & \\
for interpretation. & & \\
High levels of & & & \\
interpretation within & & \\
the constructionist & & & \\
paradigm but needing & & & \\
a strong & understanding of & & \\
context and & & & \\
consistency. & & \\
\hline
\end{tabular}

TABLE. 1.0 HERE

Caption: Methodological pluralism as triangulation 